\title{
Bilateral cochlear enhancement in Cogan syndrome
}

\section{Figure Bilateral cochlear enhancement}
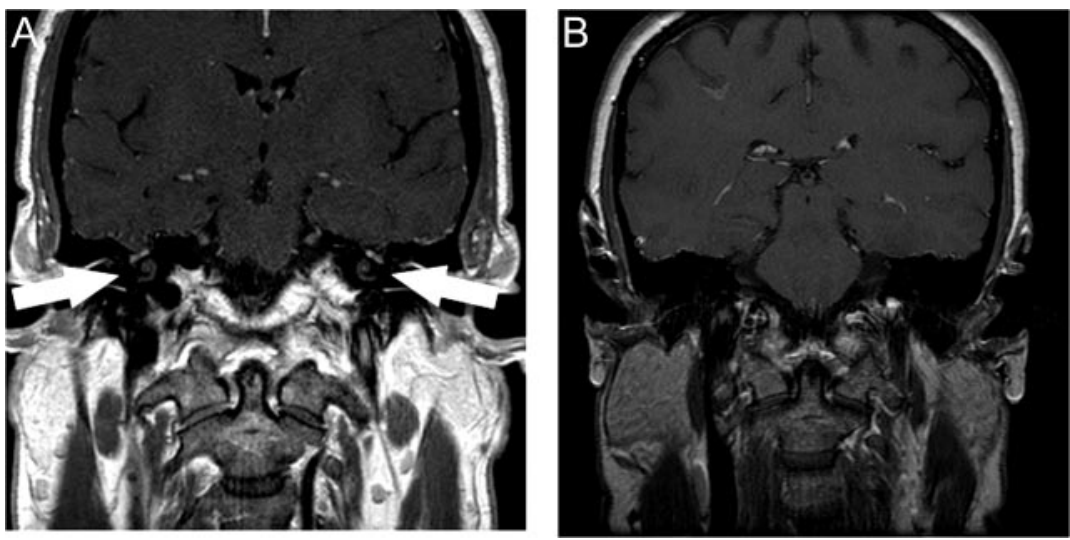

Coronal T1-weighted brain MRI with contrast highlighting bilateral cochlear enhancement (A, white arrows). Coronal T1 image with contrast for comparison shows an unaffected patient demonstrating no enhancement (B).

A 43-year-old man presented for neurologic evaluation with acute bilateral hearing loss. Two weeks before presentation, he had bilateral eye pain diagnosed as scleritis. He also noted a subacute history of fevers, night sweats, and diarrhea. Neurologic examination revealed bilateral sensorineural hearing loss, confirmed with audiometry. MRI demonstrated enhancement of the cochlea bilaterally (figure). Extensive evaluations for rheumatologic and infectious etiologies were negative.

Cogan syndrome is a rare systemic disease classified among the vasculitides characterized by audiovestibular and ocular involvement. ${ }^{1}$ The patient stabilized with oral prednisone. If refractory, treatment with steroidsparing immunosuppressants or cochlear implants can be considered. ${ }^{1}$

Jennifer E. Fugate, DO, Jonathan H. Smith, MD, Daniel O. Claassen, MD, Rochester, $M N$

Disclosure: The authors report no disclosures.

Address correspondence and reprint requests to Dr. Daniel O. Claassen, Department of Neurology, Mayo Clinic, 200 First Street SW, Rochester, MN 55905; claassen.daniel@mayo.edu

1. Mazlumzadeh M, Matteson EL. Cogan's syndrome: an audiovestibular, ocular, and systemic autoimmune disease. Rheum Dis Clin N Am 2007;33:855-874. 


\title{
Neurology
}

\author{
Bilateral cochlear enhancement in Cogan syndrome \\ Jennifer E. Fugate, Jonathan H. Smith and Daniel O. Claassen \\ Neurology 2009;73;75 \\ DOI 10.1212/WNL.0b013e3181aaea6c
}

This information is current as of June 29, 2009

\section{Updated Information \& Services}

References

Citations

Permissions \& Licensing

Reprints including high resolution figures, can be found at: http://n.neurology.org/content/73/1/75.full

This article cites 1 articles, 0 of which you can access for free at: http://n.neurology.org/content/73/1/75.full\#ref-list-1

This article has been cited by 2 HighWire-hosted articles: http://n.neurology.org/content/73/1/75.full\#\#otherarticles

Information about reproducing this article in parts (figures,tables) or in its entirety can be found online at:

http://www.neurology.org/about/about_the_journal\#permissions

Information about ordering reprints can be found online:

http://n.neurology.org/subscribers/advertise

Neurology ${ }^{\circledR}$ is the official journal of the American Academy of Neurology. Published continuously since 1951, it is now a weekly with 48 issues per year. Copyright . All rights reserved. Print ISSN: 0028-3878. Online ISSN: 1526-632X.

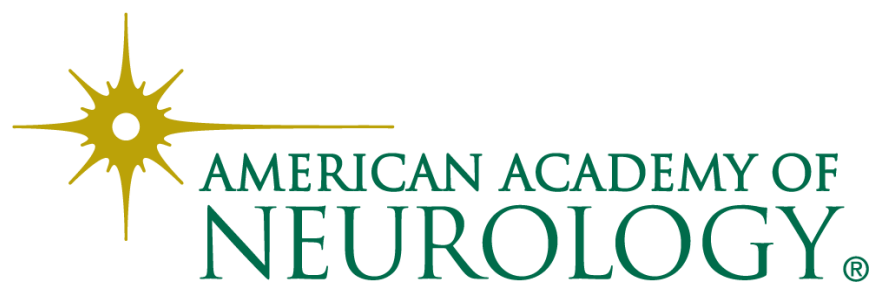

